\title{
PENGARUH MODEL PEMBELAJARAN PROJECT BASED LEARNING TERHADAP KEMAMPUAN BERPIKIR KRITIS SISWA PADA MATERI ELEKTROKIMIA
}

\author{
Fathimatuz Zahroh \\ Jurusan Kimia FMIPA Universitas Negeri Semarang \\ Gedung D6 Lantai 2 Kampus Sekaran Gunungpati Semarang, 20229, Telp (024) 8508035
}

\begin{abstract}
Project Based Learning is a learning model that need collaboration from group member in each stage, so that students can develop their critical thinking skills. The aim of this study is to determine the effect of PjBL to students' critical thinking skills on electrochemistry material. The research design used true experimental design with pretest-posttest control group design and sampling technique is cluster random sampling. The data collection techniques used pretest-posttest to understand 10 critical thinking indicators, observation sheet used to understand students' project activities and questionnaire to know students's responses. Data Analysis techniques that used in this study are average difference test, significant test, product moment correlation test, coefficient of determination test. Analysis of product moment correlation value is 0,67 for students' critical thinking skill with significant test result is 7,10 indicate the significant effect of PjBL to students' critical thingking skills on electrochemistry material. The effect of PjBL to students' critical thinking skills pointed by coefficient of determination 44,89\%. Based on the results of the study, it was conclude that PjBL had positive effects on students' critical thinking skills on electrochemistry material.
\end{abstract}

Keywords: critical thinking skills; electrochemistry; project based learning.

\section{PENDAHULUAN}

Sistem pendidikan nasional menghadapi tantangan yang sangat kompleks di era global, terutama tantangan dalam menyiapkan kualitas Sumber Daya Manusia agar dapat menghadapi persaingan di era global (Sudarmin, 2015). Permasalahan yang sering dialami oleh guru dalam menerapkan kurikulum 2013 adalah kurang aktifnya siswa dalam pembelajaran (Ilaah et.al., 2015). Selain itu, hasil PISA (Programme for International Students Assesment) menunjukkan bahwa penguasaan materi oleh siswa tergolong rendah. Hasil tersebut menunjukkan bahwa indeks prestasi siswa Indonesia 
tergolong rendah. Perolehan nilai indeks prestasi siswa yang lebih dikenal dengan hasil belajar siswa merupakan salah satu tolok ukur dalam pembelajaran (Nurbaeti et.al., 2015). Penelitian yang dilakukan oleh Wicaksono (2014) menunjukkan bahwa adanya hubungan antara kemampuan berpikir kritis dengan hasil belajar siswa. Kemampuan berpikir kritis memberikan sumbangan sebesar 41,99 \% pada hasil belajar kognitif siswa. Dengan demikian, hasil belajar yang rendah mengindikasikan kemampuan berpikir kritis siswa yang masih rendah.

Kemampuan berpikir kritis siswa yang rendah disebabkan oleh model pembelajaran yang mengajarkan kemampuan berpikir kritis tidak digunakan secara baik dalam setiap pembelajaran di kelas (Ilaah et.al., 2015). Padahal menurut Sugiarti dan Bija (2012) mutu pendidikan dapat diperoleh melalui pengembangan kemampuan berpikir siswa, sehingga guru diharapkan dapat memilih model pembelajaran yang tepat untuk diaplikasikan dalam proses belajar mengajar. Model pembelajaran yang cocok digunakan untuk melatih kemampuan berpikir kritis siswa yaitu Model PjBL.

Berpikir kritis adalah berpikir yang memiliki tujuan (membuktian suatu maksud tertentu, menafsirkan, serta memecahkan masalah), tetapi berpikir kritis dapat dilakukan dengan kolaboratif dan kompetitif (Facione, 2013). Selain itu Ennis (1995) menyebutkan 12 indikator berpikir kritis yang dapat muncul dalam proses pembelajaran. Soleimani dan Kazazi (2014) menjelaskan bahwa berpikir kritis merupakan berpikir yang bertujuan untuk memecahkan masalah, merumuskan kesimpulan, menghitung kemungkinan, dan membuat keputusan. Soleimani dan Kazazi (2014) menjelaskan bahwa berpikir kritis merupakan berpikir yang bertujuan untuk memecahkan masalah, merumuskan kesimpulan, menghitung kemungkinan, dan membuat keputusan. Haryani (2014) menunjukkan bahwa materi redoks dan elektrokimia merupakan materi yang sulit untuk siswa menurut guru kimia. Kemampuan berpikir kritis siswa diperlukan siswa untuk memahami materi yang sulit seperti materi elektrokimia. Namun tidak semua indikator berpikir kritis dapat diamati dalam proses penelitian. Pada penelitian ini, dua indikator berpikir kritis menurut Ennis (1985) tidak dapat diamati karena membutuhkan waktu yang lebih lama.

Berdasarkan hasil observasi dan wawancara dengan guru kimia kelas XII MIPA SMA Negeri 1 Kendal bahwa pada proses pembelajaran di kelas siswa terlihat aktif bertanya. Siswa sering diberikan tugas berupa soal-soal kimia yang harus diselesaikan 
ketika kegiatan belajar mengajar. Namun demikian, siswa tetap antusias dalam menyelesaikan soal-soal yang diberikan oleh guru dengan cara menanyakan cara penyelesaian soal yang dikerjakan. Antusias dan keingintahuan siswa untuk menyelesaikan soal menunjukkan adanya kemampuan berpikir kritis siswa.

Penelitian ini akan menerapkan PjBL dengan produk sel volta dan sel elektrolisis. Peserta didik diberikan penugasan berkelompok untuk merangkai sel volta dari buahbuahan dan melakukan elektrolisis logam dalam kehidupan sehari-hari menggunakan tembaga. Proses pembelajaran dilakukan untuk mengetahui pengaruh model pembelajaran PjBL terhadap kemampuan berpikir kritis siswa pada materi elektrokimia. Siswa memanfaatkan berbagai sumber untuk mendapatkan prosedur yang tepat untuk digunakan dapam proyek yang dilakukan. Proses pembelajaran aktif mencari ini dapat melatih kemampuan berpikir kritis siswa, ditunjukkan dengan 10 indikator kemampuan berpikir kritis yang dapat diamati.

Permasalahan yang akan diteliti yaitu; (1) Adakah pengaruh PjBL terhadap kemampuan berpikir kritis siswa pada materi elektrokimia, (2) Seberapa besar pengaruh model PjBL terhadap kemampuan berpikir kritis siswa. Penelitian ini bertujuan untuk mengetahui pengaruh model pembelajaran project based learning terhadap kemampuan berpikir kritis siswa pada materi elektrokimia dan tanggapan siswa terhadap pembelajaran menggunakan model project based learning.

\section{METODE PENELITIAN}

Penelitian ini dilaksanakan di SMA Negeri 1 Kendal. Teknik pengambilan sampel pada penelitian ini menggunakan teknik cluster random sampling. Sampel yang digunakan adalah kelas XII MIPA 4 sebagai kelas kontrol dan XII MIPA 5 sebagai kelas eksperimen. Jenis penelitian ini adalah True Experimental Design dengan PretestPosttest Control Group Design.

Variabel bebas pada penelitian ini adalah model pembelajaran. Kelas eksperimen menggunakan model PjBL sedangkan pada kelas kontrol menggunakan model pembelajaran kooperatif learning dengan metode ceramah, praktikum, dan diskusi. Variabel terikat pada penelitian ini yaitu kemampuan berpikir kritis siswa. Sedangkan variabel kontrol pada penelitian ini adalah kurikulum, guru, materi pembelajaran, dan jumlah jam pelajaran yang sama. 
Metode pengumpulan data menggunakan pretest-posttest untuk mengetahui kemampuan berpikir kritis siswa yang muncul pada 10 indikator, lembar observasi untuk mengamati pelaksanaan proyek, sedangkan lembar angket untuk tanggapan siswa terhadap model pembelajaran PjBL. Sebelum digunakan, soal dilakukan ujicoba pada siswa SMA Negeri 7 Semarang.

Penelitian diawali dengan memberikan soal pretest kepada siswa, kemudian kelas eksperimen melakukan pembelajaran menggunakan model pembelajaran $P j B L$, sedangkan kelas kontrol menggunakan model kooperatif learning disertai dengan praktikum dan diskusi. Proyek yang dilakukan pada kelas eksperimen adalah merangkai sel volta menggunakan buah-buahan dan melakukan penyepuhan logam yang ada di kehidupan sehari-hari menggunakan tembaga. Posttest dilakukan setelah siswa selesai mengerjakan proyek.

Uji hipotesis yang digunakan dalam penelitian ini meliputi; 1) uji perbedaan ratarata digunakan untuk menguji perbedaan rata-rata kelas eksperimen dan kontrol; 2) uji korelasi product moment untuk menentukan hubungan antara pembelajaran proyek dengan kemampuan berpikir kritis; 3) uji signifikansi untuk mengetahui kebermaknaan pengaruh yang ditunjukkan; 4) uji koefisien determinasi untuk mengetahui seberapa besar pengaruh model PjBL terhadap kemampuan berpikir kritis siswa. Tahap akhir dari penelitian ini adalah menganalisis data yang telah didapatkan kemudian menarik kesimpulan berdasarkan data yang telah dianalisis.

\section{HASIL DAN PEMBAHASAN}

Data yang digunakan untuk analisis data akhir yaitu data posttest, data hasil observasi, dan data hasil angket tanggapan siswa. Hasil posttest kemampuan berpikir kritis disajikan pada Tabel 1.

Tabel 1. Hasil Posttest KBK

\begin{tabular}{lcc}
\hline & $\begin{array}{c}\text { Kelas } \\
\text { Eksperimen }\end{array}$ & $\begin{array}{c}\text { Kelas } \\
\text { Kontrol }\end{array}$ \\
\hline Jumlah Sampel & 32 & 32 \\
Nilai Tertinggi & 87,5 & 75 \\
Nilai Terendah & 40 & 27,5 \\
Rata-rata & 66,88 & 55,23 \\
Standar deviasi & 10,57 & 11,80 \\
Varian & 111,6935 & 139,2578 \\
\hline
\end{tabular}


Pada analisis data tahap akhir dilakukan uji normalitas, uji kesamaan dua varian, dan uji hipotesis. Hasil uji normalitas disajikan pada Tabel 2.

Tabel 2. Hasil Uji Normalitas Nilai Posttest

\begin{tabular}{lc}
\hline \multicolumn{1}{c}{ Kelas } & $\chi_{\text {hitung }}^{2}$ \\
\hline Eksperimen & 6,0371 \\
Kontrol & 5,7118 \\
\hline
\end{tabular}

Tabel 2 menunjukkan bahwa data berdistribusi normal, sehingga uji selanjutnya menggunakan uji statistik parametrik. Hasil uji kesamaan dua varian menunjukkan bahwa kedua kelas memiliki varian yang sama, sehingga uji perbedaan dua rata-rata menggunakan uji t. Hasil uji perbedaan rata-rata disajikan pada Tabel 3.

Tabel 3. Hasil Uji perbedaan rata-rata

\begin{tabular}{ccc}
\hline Kelas & Thitung & Ttabel \\
\hline XII MIPA 5 & 4,1584 & 1,99 \\
XII MIPA 4 & & \\
\hline
\end{tabular}

Berdasarkan Tabel 3 dapat diketahui nilai thitung sebesar 4,158 tidak berada pada rentang yang telah ditentukan sehingga dapat ditarik kesimpulan bahwa ada perbedaan rata-rata posttest kelas eksperimen dan kelas kontrol. Nilai thitung lebih besar daripada $\mathrm{t}_{\text {tabel, }}$, berarti rata-rata kemampuan berpikir kritis siswa dengan model pembelajaran PjBL lebih baik daripada rata-rata kemampuan berpikir kritis siswa tanpa menggunakan model pembelajaran PjBL.

Perhitungan korelasi product moment dilakukan untuk mengetahui pengaruh variabel bebas terhadap variabel terikat. Hasil analisis data menunjukkan nilai $r_{x y}$ sebesar 0,67 Tanda positif pada harga $r_{x y}$ menunjukkan bahwa terjadi korelasi positif antara model $P j B L$ terhadap kemampuan berpikir kritis materi elektrokimia. Menurut pedoman interpretasi terhadap koefisien korelasi Sugiyono (2005), nilai $r_{x y}$ sebesar 0,67 Berarti bahwa pengaruh penerapan model pembelajaran PjBL tergolong memberikan pengaruh yang tinggi. Uji signifikansi untuk mengetahui kebermaknaan pengaruh yang ditunjukkan. Hasil perhitungan diperoleh $t_{\text {hitung }}=7,10$ diperoleh $t_{\text {tabel }}=1,6698$ Karena $t_{\text {hitung }}>t_{\text {tabel }}$, maka terdapat pengaruh model pembelajaran PjBL yang bersifat signifikan. Hal ini sejalan dengan penelitian Sularmi et.al., (2018) yang menunjukkan bahwa model PjBL berpengaruh signifikan dalam meningkatkan kemampuan peserta didik. Perhitungan menghasilkan KD sebesar 44,89\%. Model PjBL mempengaruhi 
kemampuan berpikir kritis siswa materi elektrokimia sebesar 44,89\%. Sedangkan $55,11 \%$ kemampuan berpikir kritis dipengaruhi oleh faktor-faktor lain yang tidak diteliti dalam penelitian ini. Faktor-faktor tersebut antara lain tingkat kesulitan materi, media pembelajaran, serta sarana dan prasarana (Aktamis \& Ergin, 2008).

Rata-rata kemampuan berpikir kritis kelas eksperimen lebih tinggi daripada kemampuan berpikir kritis kelas kontrol pada 10 indikator yang dianalisis berdasarkan hasil posttest. Perbandingan nilai indikator berpikir kritis kelas eksperimen dan kelas kontrol yang didapat melalui analisis deskriptif hasil posttest dapat dilihat pada Gambar 1.

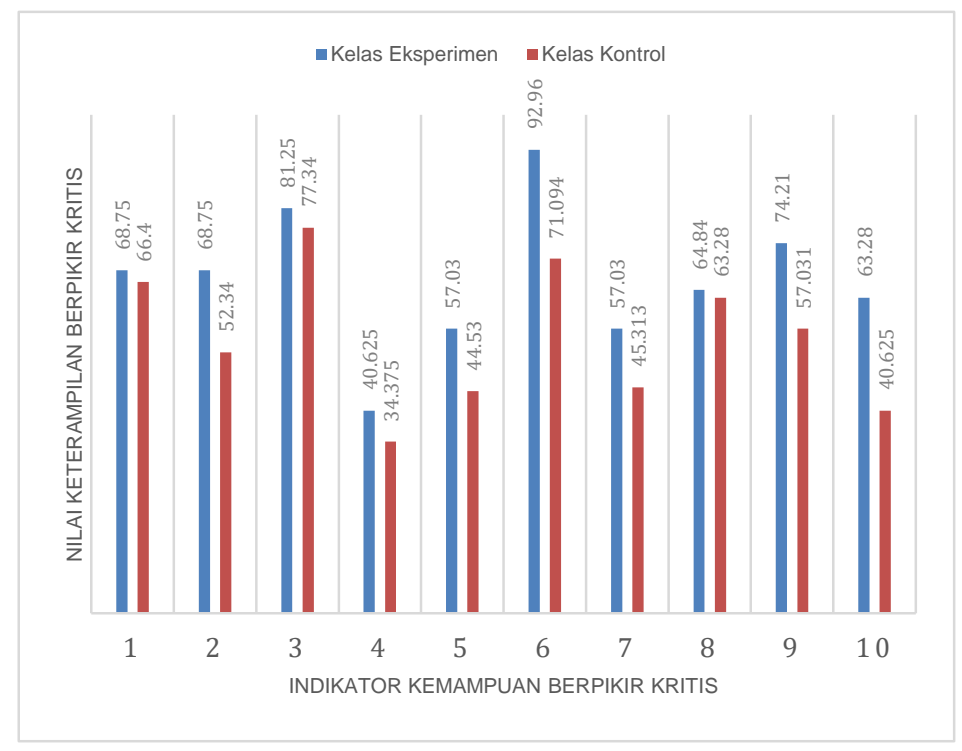

\section{Gambar 1. Hasil Posttest Kemampuan Berpikir Kritis Kelas Eksperimen dan Kontrol}

Keterangan:

1. Memfokuskan pertanyaan

2. Menganalisis argument

3. Bertanya dan menjawab pertanyaan

4. Mempertimbangkan apakah sumber dapat dipercaya atau tidak

5. Mendeduksi dan mempertimbangkan hasil deduksi

6. Menginduksi dan mempertimbangkan hasil induksi

7. Membuat dan mempertimbangkan nilai keputusan

8. Mengidentifikasi istilah

9. Mengidentifikasi asumsi

10. Memutuskan suatu tindakan

Indikator pertama kemampuan berpikir kritis yaitu indikator memfokuskan pertanyaan. Hasil posttest menunjukkan bahwa kelas eksperimen memiliki nilai lebih tinggi dibandingkan dengan kelas kontrol. Hal ini dikarenakan dalam pembelajaran proyek pada kelas eksperimen terdapat tahapan menentukan pertanyaan mendasar 
sebelum pembelajaran. Haryani et.al.,(2018) menjelaskan bahwa pertanyaan mendasar berupa pertanyaan esensial. Pada saat pertanyaan dijawab, secara langsung siswa dapat melihat berbagai elemen utama sekaligus berbagai prinsip dalam sebuah disiplin yang sedang dikajinya.

Kelas kontrol mendapatkan nilai yang lebih rendah pada indikator memfokuskan pertanyaan karena pada kelas kontrol, pembelajaran terfokus pada guru. Permasalah yang diberikan oleh guru merupakan soal latihan, sehingga siswa lebih terfokus pada soal latihan. Hal ini sesuai penelitian yang dilakukan oleh Choy (2009) yang menunjukkan bahwa salah satu faktor yang mempengaruhi siswa belum bisa mengembangkan kemampuan berpikir kritis karena hanya berorientasi pada latihan soal saja.

Indikator kedua pada kemampuan berpikir kritis adalah indikator menganalisis argumen. Hasil posttest kelas eksperimen yaitu 68,75 dengan predikat baik dan hasil posttest kelas kontrol yaitu 52,34 dengan predikat cukup. Kelas eksperimen mendapatkan nilai lebih baik karena dalam pembelajaran proyek, siswa terlatih untuk berdiskusi. Llewellyn (2013) mengemukakan bahwa diskusi dapat memfasilitasi siswa untuk membangun argumentasi ilmiah dengan cara memberi kesempatan siswa untuk berpendapat dan memberikan penolakan.

Indikator ketiga adalah bertanya dan menjawab pertanyaan. Kedua kelas mendapatkan nilai dengan kategori baik karena pertanyaan mendasar yang diberikan oleh guru pada pembelajaran proyek meningkatkan keingintahuan siswa untuk mencari jawaban dari permasalahan yang diberikan oleh guru. Selain itu, siswa kelas eksperimen terlatih untuk berdiskusi dalam perencanaan proyek sehingga terbiasa untuk bertanya dan menjawab pertanyaan. Kelas kontrol mendapatkan nilai dengan kategori baik karena guru memberikan contoh dalam kehidupan sehari-hari yang berkaitan dengan materi, sehingga siswa tertarik untuk bertanya. Hal ini sesuai dengan penelitian yang dilakukan oleh Yunita et.al., (2018) yang menunjukkan bahwa guru dapat meningkatkan berpikir kritis siswa dengan cara memberikan contoh dalam kehidupan sehari-hari yang berkaitan dengan materi.

Indikator keempat yaitu indikator apakah sumber dapat dipercaya atau tidak. Indikator apakah sumber dapat dipercaya atau tidak merupakan indikator dengan perolehan paling sedikit karena kurangnya waktu sehingga siswa kurang maksimal 
dalam memilih sumber yang dapat dipercaya atau tidak. Kelas eksperimen mendapatkan nilai lebih tinggi karena dalam pembelajaran berbasis proyek siswa harus memperhatikan apakah prosedur yang digunakan dalam rancangan proyek sudah tepat atau belum, dan kesesuaian sumber dalam menyusun rancangan proyek. Siswa mencari dari berbagai sumber untuk menemukan prosedur terbaik untuk melaksanakan proyek yang akan dibuat. Sedangkan pada kelompok kontrol dengan metode ceramah, diskusi dan praktikum. Ceramah yang baik harus divariasikan dengan metode pembelajaran lain agar siswa aktif dalam melakukan kegiatan (Tambak, 2014).

Kelompok kontrol tidak terbiasa mempertimbangkan apakah prosedur yang digunakan tepat atau tidak karena prosedur yang akan digunakan sudah tersedia. Diskusi dilakukan berkelompok untuk membahas permasalahan berupa latihan-latihan soal sehingga siswa terfokus pada cara menyelesaikan soal. Hal ini yang menyebabkan kelas eksperimen mendapatkan nilai lebih tinggi pada indikator apakah sumber dapat dipercaya atau tidak.

Indikator kelima yang diamati yaitu mendeduksi dan mempertimbangkan hasil deduksi. Kedua kelas mendapatkan kategori cukup. Kelas kontrol mendapatkan nilai 44,53 dan kelas eksperimen mendapatkan nilai 57,03. Berdasarkan data posttest, kedua kelas memperoleh kategori cukup karena siswa dapat menganalisis apakah reaksi berlangsung spontan atau tidak, tetapi hanya sedikit siswa yang menuliskan kesimpulan dari umum ke khusus (deduksi) dan menuliskan pendapatnya. Mutakinati (2018) menyebutkan bahwa siswa kemampuan berpikir kritis yang kurang disebabkan oleh kemampuan berpikir logis yang rendah. Sejalan dengan Mutakinati, penelitian yang dilakukan oleh Sutinah (2015) menunjukkan bahwa salah satu rendahnya kemampuan logika yang dimiliki siswa karena siswa belum mampu dalam menghubungkan konsep prasyarat dengan konsep yang dipelajari.

Indikator keenam yaitu menginduksi dan mempertimbangkan hasil induksi. Menarik kesimpulan sesuai fakta adalah tujuan dari indikator ini. Indikator ini merupakan indikator dengan perolehan nilai paling tinggi karena kedua kelas terbiasa untuk menarik kesimpulan dari materi dan peristiwa yang dialami dalam praktikum menjadi kesimpulan yang bersifat umum . Hal ini sejalan dengan penelitian Sutinah (2015) yang menunjukkan bahwa indikator menginduksi dan mempertimbangkan hasil induksi memperoleh nilai yang paling tinggi pada pembelajaran proyek dibandingkan 
dengan indikator lain.

Indikator ketujuh yaitu membuat dan mempertimbangkan nilai keputusan diamati berdasarkan hasil posttest. Kelas eksperimen mendapatkan nilai 57,03 dengan kategori cukup dan kelas kontrol mendapatkan nilai 45,313 dengan kategori cukup. Kedua kelas memperoleh kategori cukup karena rata-rata terjadi kesalahan dalam menentukan volume $\mathrm{Cl}_{2}$ yang terbentuk. Ketelitian diperlukan untuk memperimbangkan suatu keputusan berdasarkan fakta. Hal ini sesuai dengan pendapat Ennis (1995) yang menyebutkan bahwa dalam membuat dan mempertimbangkan suatu nilai keputusan berdasarkan fakta harus dilakukan dengan teliti, karena kita harus bisa membedakan mana suatu fakta atau bukan fakta. Wijayanti et.al., (2018) mengungkapkan bahwa agar mampu memecahkan masalah dengan baik dituntut kemampuan analisis, sintesis, evaluasi, generalisasi, membandingkan, mendeduksi, mengklasifikasi informasi, menyimpulkan, dan mengambil keputusan.

Indikator kedelapan adalah mengidentifikasi istilah. Hasil posttest menunjukkan bahwa kelas eksperimen dan kelas kontrol mendapatkan kategori yang sama yaitu baik. Selisih nilai antara kelas eksperimen dan kelas kontrol sangat sedikit. Kelas eksperimen mendapatkan nilai 64,84 dan kelas kontrol mendapatkan nilai 63,28 dengan kategori. Fitrianingsih, Umamah dan Na'im (2015) berpendapat bahwa jika siswa tidak kebingungan dalam menjawab pertanyaan, maka siswa memiliki kemampuan yang baik dalam mendefinisikan istilah. Sejalan dengan pendapat Fitrianingsih, Umamah dan Na'im (2015), Kedua kelas tidak terlalu kebingungan dalam menjelaskan perbedaaan sel volta dan sel elektrolisis sehingga kelas eksperimen maupun kontrol memiliki kemampuan yang baik dalam mendefinisikan istilah.

Indikator kesembilan adalah mengidentifikasi asumsi. Hasil posttest menunjukkan bahwa kelas eksperimen menadapatkan nilai 74,21 dengan kategori baik dan kelas kontrol mendapatkan nilai 57,031 dengan kategori cukup. Pada indikator menganalisis asumsi, kelas eksperimen dapat menalar suatu peristiwa elektrolisis yang tidak memerlukan jembatan garam dengan menggunakan dasar teori berupa fungsi jembatan garam kemudian dikaitkan dengan kondisi pada sel elektrolisis. Sedangkan pada kelas kontrol siswa hanya dapat menjelaskan fungsi jembatan garam saja. Hal ini dikarenakan dalam pembelajaran Proyek, siswa terlatih untuk mengidentifikasi suatu masalah yang diberikan guru. Haryani et.al., (2017) menyebutkan bahwa ketika 
melakukan identifikasi masalah, siswa mendapatkan kesempatan untuk menganalisis data dan informasi yang dapat digunakan untuk mendukung pendapatnya dalam suatu masalah tersebut.

Indikator kesepuluh adalah indikator memutuskan suatu tindakan. Pada indikator ini kelas eksperimen mendapatkan nilai 63,28 dengan kategori baik dan kelas kontrol mendapatkan nilai 40,625 dengan kategori cukup. Selain itu, pembelajaran dengan model PjBL pada kelas eksperimen melatih siswa untuk membuat keputusan dari permasalahan yang dihadapi. Hai ini sesuai dengan pendapat Isnur et.al., (2018) menjelaskan bahwa pembelajaran dengan model PjBL membuat siswa aktif dalam hal membuat keputusan, merancang solusi, bertanggungjawab dalam mencari dan mengelola informasi. Pelaksanaan proyek pertama yaitu menyusun sel volta dengan menggunakan buah-buahan mendapatkan hasil lebih baik daripada pelaksanaan proyek kedua yaitu penyepuhan logam yang ada dalam kehidupan sehari-hari menggunakan tembaga. Hasil penilaian pelaksanaan proyek dapat dilihat pada Tabel 4.

\section{Tabel 4. Penilaian Pelaksanaan Proyek}

\begin{tabular}{lcc}
\hline \multicolumn{1}{c}{ Aspek } & Proyek 1 & Proyek 2 \\
\hline Rancangan proyek & 81,04 & 80,4 \\
Persiapan & 77,92 & 76,3 \\
Langkah kerja & 73,13 & 75,0 \\
Kecekatan kerja & 78,75 & 79,8 \\
Kerjasama kelompok & 73,33 & 77,3 \\
Ketepatan rencana dan pelaksanaan & 81,88 & 79,0 \\
Praktikum & 62,04 & 77,06 \\
Produk & 83,4 & 67,2 \\
Laporan akhir & 81,25 & 81,0 \\
Ketepatan waktu pengumpulan hasil & 92,92 & 78,6 \\
\hline
\end{tabular}

Pelaksanaan proyek pertama lebih baik karena perencanaan yang dilakukan dengan baik dan waktu yang mencukupi. Pada proyek sel volta menggunakan buahbuahan, dua kelompok menggunakan bahan yang sama yaitu buah jeruk. Sedangkan pada proyek sel elektrolisis penyepuhan logam yang ada dalam kehidupan sehari-hari siswa banyak menggunakan koin dan paku. Kesamaan bahan yang digunakan dalam penelitian karena siswa mudah menemui bahan-bahan tersebut dalam kehidupan seharihari. Kim (2011) mengatakan bahwa ketika siswa diberikan contoh dari suatu objek kemudian diminta untuk memodifikasi objek, siswa cenderung untuk mencontoh objek yang pernah dilihat. 


\section{SIMPULAN}

Pengaruh Model pembelajaran Project Based Learning pada Kemampuan berpikir kritis siswa diukur menggunakan tes yaitu posttest. Rata-rata posttest kelas eksperimen sebesar 66,8 dan kelas kontrol sebesar 55,23 kemudian dilakukan perhitungan korelasi product moment, koefisien determinasi dan uji signifikansi. Model pembelajaran Project Based Learning berpemgaruh positif terhadap kemampuan berpikir kritis siswa materi elektrokimia ditunjukkan dengan hasil perhitungan korelasi product moment. Menurut pedoman interpretasi terhadap koefisien korelasi Sugiyono (2005), nilai $\mathrm{r}_{\mathrm{xy}}$ sebesar 0,67 menunjukkan bahwa bahwa pengaruh penerapan model pembelajaran $\mathrm{PjBL}$ tergolong memberikan pengaruh yang tinggi. Uji signifikansi menunjukkan bahwa pengaruh yang diberikan bersifat signifikan. Model pembelajaran project based learning memberikan pengaruh sebesar $44,89 \%$ terhadap kemampuan berpikir kritis siswa pada materi elektrokimia. Sedangkan 55,11\% kemampuan berpikir kritis dipengaruhi oleh faktor-faktor lain yang tidak diteliti dalam penelitian ini. Pengaruh yang diberikan termasuk kategori signifikan dan tinggi. Berdasarkan hasil penelitian dapat disimpulkan bahwa model Pembelajaran project based learning memberikan pengaruh postif terhadap kemampuan berpikir kritis siswa pada materi elektrokimia.

\section{DAFTAR PUSTAKA}

Aktamis. H dan Ergin, O. (2008). The Effect of Scientific Process Skills Education on Students' Scientific Creativity, Science Attitudes and Academic Achievements. Asia Pacific Forum on Science Learning and Teaching, 9(1), 1-15.

Choy, S Chee dan Phaik Kin Cheah. (2009). Teacher Percepcions of Critical Thinking Among Students and Its Influence on Higher Education. Journal of Teaching and Learning in Higher Education. 20(2), 202.

Ennis, Robert H. (1995). Critical Thinking. New Jersey: Prentice Hall.

Facione, Peter. (2013). Critical Thinking: What It is and Why It Counts. Milbrae: Measured Reasons and The California Academic Press.

Fitrianingsih, Rahmawati N.U., dan Moh. N., (2015). Penerapan Model Pembelajaran Berbasis Proyek untuk Meningkatkan Kemampuan Berpikir Kritis dan Hasil Belajar Sejarah Peserta Didik Kelas X SOS di SMA N 4 Jember Tahun Ajaran 2014/2015. Jurnal Edukasi UNEJ. 2(1), 32-36.

Haryani, Sri., Sri Wardani dan Agung Tri Prasetya. (2018). Analisis Kemampuan Penyusunan Lembar Kerja Siswa Berbasis Problem Based Learning dan Project Based Learning. Jurnal Inovasi Pendidikan Kimia., 12(1), 2086-2096.

Haryani, Sri, Masfufah., N Wijayati, dan C Kurniawan. (2017). Improvement of metacognitive skills and students' reasoning ability through problem-based 
learning. Proceeding. Semarang: International Conference on Mathematics, Science and Education.

Ilaah, Yuni Faidlul dan Bertha Yonata. (2015). Keterampilan Berpikir Kritis Siswa SMA Kemala Bhayangkari 1 Surabaya Pada Materi Laju Reaksi Melalui Penerapan Model Pembelajaran Inkuiri. UNESA Journal Of Chemical Education. 1(1), 78-83.

Isnur, Suranto, et.al. (2018). Efektifitas Model Pembelajaran Project Based Learning Terhadap Kemampuan Berpikir Kritis Materi Bangun Ruang Kelas VII. Proceeding. Semarang: Seminar Nasional Edusaintek FMIPA UNIMUS.

Kim, K. H., (2011). The Creativity Crisis: The Decrease in Creative Thinking Scores on Torrance Test of Creative Thinking. Creativity Research Journal. 2(4), 285-295.

Llewellyn. (2013). Teaching High Scholl Science Through Inquiry and Argumentation. USA: Corwin.

Mutakinati. (2018). Analysis of Student's Critical Thinking of Middle School Through STEM Education Project Based Learning. Jurnal Pendidikan IPA Indonesia. 7(1), 54-65.

Nurbaeti, Siti Nuryanti dan Indarini Dwi Pursitasari. (2015). Hubungan Gaya Belajar dengan Keterampilan Berpikir Kritis dan Kemampuan Kognitif Siswa pada Mata Pelajaran Kimia di Kelas X SMKN 1 Bungku Tengah. e-jurnal mitra Sains, 3(2), 22-23.

Obamanu, B.J dan Onouha C.O. (2012). Students Conceptual Difficulties in Electrochemistry in Senior Secondary School. Journal of Emerging Trends in Educational Reaserch and Policy Studies (JETERAPS). 3(1), 99-102.

Hasan dan Nahid Ghavani Kazazi. (2014). Critical Thinking and Writing: The Effects of Critical Thinking on Writing Skill among Iranian University Students Majority in TEFL. International Journal of Language Learning and Applied Linguistic World (IJLLALN), 5(4), 254-266.

Sastrika, I.A.K, I Wayan Sadia dan I Wayan Muderawan. (2013). Pengaruh Model Pembelajaran Berbasis Proyek Terhadap Pemahaman Konsep Kimia dan Keterampilan Berpikir Kritis. E-Journal Program Pascasarjana Universitas Pendidikan Ganesha,.3.

Sudarmin. (2015). Model Pembelajaran Inovatif Kreatif (Model Paikem dalam Konteks Pembelajaran dan Penelitian Sains Bermuatan Karakter). Semarang: Fakultas Matematika dan Ilmu Pengetahuan Alam.

Sugiarti dan Stephanie Bija. (2012). Pengaruh Model Kontekstual Terhadap Kemampuan Berpikir Kritis Siswa Kelas XI IA SMA Negeri 3 Watansoppeng. Jurnal Chemica, 13(1), 77-83.

Sularmi, et.al., 2018. Pengaruh Project Based Learning terhadap Kemampuan Berpikir Kritis. Jurnal Pendidikan: Teori, Penelitian, dan Pengembangan, 3(4), 475-479.

Sutinah. (2015). Analisis Keterampilan Berpikir Kritis Siswa melalui Model Pembelajaran Berbasis Proyek pada Materi Larutan Elektrolit dan Larutan Non Elektrolit. Skripsi. Jakarta: UIN Syarif Hidayatullah.

Tambak, S. (2014). Metode Ceramah: Konsep dan Amplikasi dalam Pembelajaran Pendidikan Agama Islam. Jurnal Tarbiyah, 21(2), 375-401.

Ristyani Erika dan Evi Sapinatul Bahriah. (2016). Analisis Kesulitan Belajar Kimia Siswa di SMA N X Kota Tangerang Selatan. Jurnal Penelitian dan Pembelajaran IPA, 2(1), 18-29.

Wicaksono, A.G. Candra. (2014). Hubungan Keterampilan Metakognitif dan Berpikir 
Kritis terhadap Hasil Belajar Kognitif Siswa SMA pada Pembelajarn Biologi dengan Strategi Reciprocal Teaching. Jurnal Pendidikan Sains, 2(2), 85-92.

Wijayanti, D. A. I. et al. (2015). Analisis Kemampuan Berpikir Kritis Siswa Kelas V dalam Pembelajaran IPA di 3 SD Gugus X Kecamatan Buleleng. E-Journal PGSD Universitas Pendidikan Ganesha Jurusan PGSD, 3(1).

Yunita, Selly. (2018). Analisis Kemampuan Berpikir Kritis Mata Pelajaran Kimia Pada Siswa Kelas XI IPA SMA N 1 Kepahiang. ALOTROP, Jurnal Pendidikan dan Ilmu Kimia, 2(1): 33-38.

Zajkov, O. dan Mitrevski, B. (2012). PBL: Dillemas and Questions! Macedonian Physics Teacher, 48: 1-11. 